J. Clin. Chem. Clin. Biochem.

Vol. 20,1982 , pp. $447-450$

\title{
The Measurement of Erythrocyte Ammonia Using the Hyland Ammonia Kit
}

\author{
By J. E. Buttery
}

Department of Clinical Chemistry, The Queen Elizabeth Hospital, Woodville, South Australia

R. N. Ratnaike

Department of Medicine, University of Adelaide, South Australia and

\section{B. R. Chamberlain}

Department of Clinical Chemistry, The Queen Elizabeth Hospital, Woodville, South Australia

(Received September 15/December 15, 1981)

Summary: We modified the Hyland Ammonia kit for plasma to measure blood ammonia from which the erythrocyte ammonia is calculated. Our modified method gave good recoveries and its precision based on replicate assays was excellent $(\mathrm{CV}<3.0 \%)$. The within-day and day-to-day precision was determined from pooled blood and aqueous ammonia solution respectively. The precision calculated from duplicate results was not as good but agreed with other published values.

A critical examination of Hyland's method showed the efficiency of resin adsorption to be $78 \%$, and that the resin caused a $16 \%$ reduction in the Berthelot reaction, while $4 \mathrm{~mol} / 1 \mathrm{NaCl}$ increased the reaction by about $11 \%$.

Blood specimens for ammonia can be frozen but specimen instability occurred during the thawing process. Measurement of ammonia directly on frozen specimens overcomes this problem.

The reference range for eirythrocyte ammonia was $14.5-46.1$ (mean 30.1, SD 7.9) $\mu \mathrm{mol} / 1$.

\section{Bestimmung von Ammoniäk in Erythrocyten mit dem Hyland Ammoniak-Testbesteck}

Zusammenfassung: Das Hyland Testbesteck für Ammoniak im Plasma wurde für die Bestimmung des Ammoniaks im Blut, aus der dạs Ammoniäk in Erythrocyten berechnet wird, modifiziert. Die modifizierte Methode ergab eine gute Wiederfindung, und ihre Präzision aufgrund von Wiederholungsmessungen war hervorragend (VK $<3,0 \%$ ). Die Präzision in der Serie und von Tag zu Tag wurde an einem Blutpool und wäßrigen Ammoniaklösungen ermittelt. Die aus Doppelbestimmungen ermittelte Präzision war weniger gut, stimmte aber mit anderen publizierten Werten überein.

Eine kritischere Untersuchung der Hyland-Methode ergab, dạß die Adsorption an das Austauscherharz $78 \%$ beträgt und das Austauscherharz eine Verminderung der Berthelot-Reaktion von $16 \%$ verursachte, während $4 \mathrm{~mol} / 1 \mathrm{NaCl}$ die Reaktion um etwa $11 \%$ verstärkte.

Blutproben zur Ammoniakbestimmung können eingefroren werden, jedoch tritt während des Auftau-Prozesses Probeninstabilitạtt auf. Dieses Problem kann durch dịrekte Messung des Ammoniak in gefrorenen Probẹn bewältigt werden.

Der Referenzbereich für Ammoniak in Erythrocyten beträgt 14,5 bis 46,1 $(\bar{x}=30,1 ; s=7,9) \mu \mathrm{mol} / 1$.

\section{Introduction}

The measurement of plasma ammonia by the Hyland Ammonia Test kit (1) has been our routine method for several years. The assay involves the selective adsorption of ammonia from plasma onto a strongly acidic cation exchange resin. The resin, which is in a slurry, is added to plasma diluted in water. After 5 min mixing and several washes of the resin with water, the ammonia was 
eluted from the resin with $4 \mathrm{~mol} / 1 \mathrm{NaCl}$. It is quantitated by reacting it with phenol and hypochlorite in the presence of sodium nitro-ferricyanide (Berthelot reaction) to form a stable, dark-blue, indophenol complex.

In the quest for a better assessment of portosystemic encephalopathy, our initial investigations indicated the usefulness of erythrocyte ammonia in comparison to plasma ammonia. We therefore ciritically examined the Hyland kit for its possible adaption to the measurement of blood ammonia from which the erythrocyte ammonia concentration is derived.

\section{Materials and Methods}

$20 \mathrm{ml}$ of venous blood was drawn from the ante cubital vein, without stasis, into plastic syringes. Heparin was not used. The blood was transferred without air bubbles into vacutainer tubes containing EDTA (Becton-Dickinson, Rutherford, New Jersey 07070, U.S.A.) and placed on ice immediately. A portion of the blood was used for the measurement of the packed cell volume.

Plasma was separated following centrifugation at $2000 \mathrm{~g}$ for 10 $\min$ at $0{ }^{\circ} \mathrm{C}$. The estimation of plasma and blood ammonia was done within $30 \mathrm{~min}$ after blood collection. If this was not possible, $1.0 \mathrm{ml}$ of the specimens in duplicate were snap frozen in acetone-dry ice and stored at $-20^{\circ} \mathrm{C}$.

Ammonia was measured using the commercially available Hyland Ammonia Test kit (1).

For the measurement of blood ammonia a dilution of 1 in 4 using ammonia-free water was made while for plasma the dilution was 1 in 3 as recommended by the manufacturer. After the addition of the resin, the tubes containing blood were washed four times instead of thrice as is done for plasma.

\section{Experimental}

\section{Blood ammonia and recovery study}

The suitability of blood for the measurement of ammonia was investigated by comparing varying dilutions of blood and their ability to recover a known concentration of ammonia

$(100 \mu \mathrm{mol} / \mathrm{l})$. The procedure was as follows: One millilitre of ammonia solution $(100 \mu \mathrm{mol} / \mathrm{l})$ was added to each of five tubes containing between 1 and $5 \mathrm{ml}$ of ammonia-free water, followed by $1.0 \mathrm{ml}$ of blood into each tube. This gave dilutions of blood ranging from 1 in 3 to 1 in 7 . Resin was added to each tube and the ammonia quantitated using ammonia standards similarly diluted.

\section{Erythrocyte ammonia}

The erythrocyte ammonia concentration is calculated from the following equation (2):

Erythrocyte ammonia $(\mu \mathrm{mol} / 1)=\frac{\mathrm{B}-\mathrm{NH}_{3}-\left[(1-\mathrm{PCV}) \cdot \mathrm{P}-\mathrm{NH}_{3}\right]}{\mathrm{PCV}}$

B- $\mathrm{NH}_{3}=$ blood ammonia $(\mu \mathrm{mol} / \mathrm{l})$

$\mathrm{P}-\mathrm{NH}_{3}=$ plasma ammonia $(\mu \mathrm{mol} / \mathrm{l})$

$\mathrm{PCV}=$ packed cell volume fraction

\section{Precision}

Due to problems associated with specimen instability, the day-today precision study on blood ammonia was not possible. This was however carried out using aqueous ammonia solution.

The within-day precision for blood ammonia was done on expired blood from the blood bank on 3 occasions. Using duplicate results from 47 healthy people, the precision of the measurement of plasma, blood and erythrocyte ammonia was determined as suggested by Henry \& Dryer (3).

\section{Resin efficiency}

When an ammonia solution $(100 \mu \mathrm{mol} / \mathrm{l})$ is carried through the Hyland kit procedure and compared to another ammonia solution of similar concentration in the presence of $4 \mathrm{~mol} / 1$ $\mathrm{NaCl}$ and "dry" resin (liquid rêmoved from resin șlurry), the efficiency of the resin to adsorb ammonia in the first tube can be determined. In the second tube the ammonia is not adsorbed by the resin owing to the $\mathrm{NaCl}$ and is measured totally.

The effects of resin and $4 \mathrm{~mol} / 1 \mathrm{NaCl}$ on the development of the Berthelot reaction were investigated.

\section{Specimen stability}

Blood ammonia has been shown to be stable for at least 8 days when stored at $-20^{\circ} \mathrm{C}(4)$. It is during thawing that blood may become unstable and this was investigated by thawing blood and plasma specimens in a water bath at room temperature (about $23^{\circ} \mathrm{C}$ ) and at $37^{\circ} \mathrm{C}$ for varying lengths of time.

\section{Results and Discussion}

\section{Blood ammonia and recovery study}

The recovery of ammonia from the various dilutions of blood is shown in table 1 . Although the best recovery (mean) was at the dilution of 1 in 3 , the smallest difference between recovery was at the 1 in 4 dilution. This dilution was therefore used for the assay of blood ammonia as it gave the best precision. It would appear that the method is suitable for the measurement of ammonia in blood and that blood did not interfere in the assay.

The accuracy in the measurement of blood ammonia cannot be properly assessed as there are no appropriate reference methods or reference material. An indirect approach to accuracy assessment is through recovery studies. At the recommended blood dilution of 1 in 4 , the recovery of ammonia ranged from $95-104 \%$, mean 99\% (tab. 1). According to the criterion of Logan (5), this is acceptable as no single recovery was less than $85 \%$ or more than $115 \%$.

Additional recovery experiments to include normal and elevated ammonia levels showed that the recoveries were $90 \%$ and $92 \%$ for $35 \mu \mathrm{mol} / 1$ and $200 \mu \mathrm{mol} / 1$ ammonia concentrations respectively. The recoveries are the mean values of triplicate assays.

Tab. 1. The recovery of ammonia $(100 \mu \mathrm{mol} / \mathrm{l})$ from bloōd at different dilutions.

\begin{tabular}{llll}
\hline Dilution & $\begin{array}{l}\text { Range of } \\
\text { recovery } \\
(\%)\end{array}$ & $\begin{array}{l}\text { Difference } \\
\text { in recovery } \\
\text { range }(\%)\end{array}$ & $\begin{array}{l}\text { Mean } \\
\text { recovery } \\
(\%)\end{array}$ \\
\hline 1 in $3(n=5)$ & $93-105$ & 12 & 100 \\
1 in $4(n=7)$ & $95-104$ & 9 & 99 \\
1 in $5(n=6)$ & $92-109$ & 17 & 99.3 \\
1 in $6(n=7)$ & $90-106$ & 16 & 98.8 \\
1 in $7(n=7)$ & $85-106$ & 21 & 95.7 \\
\hline
\end{tabular}




\section{Precision}

The day-to-day precision for the measurement of aqueous ammonia solution $(107 \mu \mathrm{mol} / 1)$ had a $\mathrm{CV}$ of $2.8 \%$ (tab. 2) which was superior to that reported by Hyland (1). The within-day precision for the three blood samples was also excellent, averaging a $\mathrm{CV}$ of $2.6 \%$.

Based on the duplicate assays, the precision (95\% limits) for the measurement of plasma, blood and ery throcyte ammonia in the respective reference ranges is shown in table 3. These values reflect the total precision of the assay which is the within-day and day-to-day precision. The precision thus determined was generally poor, especially for erythrocyte ammonia which is derived from the plasma and blood ammonia concentrations. Our CV for plasma ammonia is $7.8 \%$ compared with $8.4 \%$ reported by Gerron et al. (6). In both studies the CV was derived from duplicate results.

Tab. 2. Day-to-day and within-day precision.

\begin{tabular}{llccc}
\hline & $\begin{array}{l}\text { Day-to-day } \\
\text { Aqueous } \\
\text { ammonia } \\
\text { solution }\end{array}$ & \multicolumn{2}{l}{ Within day } \\
& Blood A & & & \\
& & & & \\
\hline Mean $(\mu \mathrm{mol} / 1)$ & 107 & 602 & 522 & 552 \\
S.D. $(\mu \mathrm{mol} / 1)$ & 3.0 & 21.4 & 13.8 & 9.9 \\
CV $(\%)$ & 2.8 & 3.5 & 2.6 & 1.8 \\
n & 48 & 9 & 12 & 11 \\
\hline
\end{tabular}

Tab. 3. The precision of the measurement of plasma, blood and ery throcyte ammonia derived from duplicate results.

\begin{tabular}{lllll}
\hline Material & $\begin{array}{l}\text { Range } \\
(\mu \mathrm{mol} / \mathrm{l})\end{array}$ & $\begin{array}{l}\text { Mean } \\
(\mu \mathrm{mol} / \mathrm{l})\end{array}$ & $\begin{array}{l}\mathrm{CV} \\
(\%)\end{array}$ & $\begin{array}{l}\text { “95\% } \\
\text { limits" }\end{array}$ \\
\hline $\begin{array}{l}\text { Plasma } \\
(\mathrm{n}=47)\end{array}$ & $8.6-34.9$ & 20.8 & 7.8 & 15.3 \\
$\begin{array}{l}\text { Blood } \\
(\mathrm{n}=47)\end{array}$ & $11.7-37.7$ & 24.6 & 7.4 & 14.8 \\
$\begin{array}{l}\text { Erythrocyte } \\
(\mathrm{n}=47)\end{array}$ & $16.3-47.0$ & 29.9 & 16.4 & 32.8 \\
$\begin{array}{l}\text { Erythrocyte } \\
\text { (abnormal, } \\
n=13)\end{array}$ & $65.2-368$ & 136.6 & 6.1 & 13.2 \\
\hline
\end{tabular}

\section{Resin efficiency}

The Hyland procedure measured $78 \%$ of the ammonia through resin adsorption. When the aqueous solution in contact with the resin was assayed, the remaining $22 \%$ of ammonia was recovered. Thus the resin efficiency is about $78 \%$. To achieve "accuracy" in the measurement of ammonia by the Hyland procedure, the test samples (plasma or blood) and the ammonia standard are carried out under similar assay conditions.

Resin affected the Berthelot reaction by suppressing it $16 \%$. This was shown by comparing the reaction on an ammonia solution $(100 \mu \mathrm{mol} / 1)$ prepared in $4 \mathrm{~mol} / 1$ $\mathrm{NaCl}$ with and without resin. The resin was in the "dry" form. Measurement of the supernatant from the tube containing resin showed no adsorption of the ammonia onto the resin and that the $16 \%$ suppression was entirely owing to the resin.

A second factor affecting the Berthelot reaction was the presence of $4 \mathrm{~mol} / 1 \mathrm{NaCl}$. Ammonia solution developed with and without $4 \mathrm{~mol} / 1 \mathrm{NaCl}$, in the absence of resin, showed an increase of about $11 \%$ in colour caused by the $\mathrm{NaCl}$.

In the study of Oberholzer et al. (7), which did not take into account the effect of resin on the Berthelot reaction, the resin efficiency averaged $63 \%$. Under similar conditions our figure was $64 \%$. However, if the effects of the resin and $4 \mathrm{~mol} / 1 \mathrm{NaCl}$ are considered, the resin efficiency is $78 \%$. This is the maximum resin efficiency in the Hyland method in our hands. It is important therefore that any study on resin efficiency should consider these factors which are not generally appreciated.

\section{Specimen stability}

Blood when thawed at room temperature showed an average increasse in ammonia concentration of about $4 \%$ by $8 \mathrm{~min}$ while at $37^{\circ} \mathrm{C}$ it averaged a $7.4 \%$ increase by $1 \mathrm{~min}$. Plasma ammonia was less affected generally at the two thawing temperatures.

Frozen blood specimen is unstable during the thawing process because considerable time is required for proper thawing before it can be sampled for the assay. To overcome this problem, blood was accurately dispensed into $1.0 \mathrm{ml}$ portions and frozen. The assay can then be carried out at a convenient time by adding the water and resin to the frozen specimen. Thus there is minimal delay in thawing and this is the most effective way to measure ammonia in frozen specimens.

\section{Reference range}

The reference range of 47 normal hospital employees (22 men and 25 women) for erythrocyte ammonia was $14.5-46.1$ (mean 30.1 ; SD 7.9) $\mu \mathrm{mol} / 1$. There was no significant sex-related difference (unpaired $t$-test).

\section{General comments}

In a preliminary study, plasma and erythrocyte ammonia concentrations were measured in a group of patients with liver disease. Patients with clinical evidence of portosystemic encephalopathy had significantly elevated plasma and erythrocyte ammonia as compared to those with no evidence of portosystemic encephalopathy. Forty-two percent of the patients with portosystemic encephalopathy had plasma ammonia levels in the same range as the non-portosystemic encephalopathy patients but with ery throcyte ammonia no overlapping values were noted. Thus it would appear that plasma ammonia is a less reliable discriminator of portosystemic encephalopythy but that erythrocyte ammonia is a better biochemical index of portosystemic encephalopathy. 


\section{References}

1. Hyland Blood Ammonia Test: A colorimetric method for the quantitative determination of ammonia nitrogen in plasma. Travenol Laboratories International, Deerfield, Illinois 60015, U.S.A.

2. Humoller, F. L., Barak, A. J. \& Holthaus, J. M. (1964) Clin. Chem. 10, 589-596.

3. Henry, R. J. \& Dryer, R. L. (1963) Stand. Meth. Clin. Chem. 4, 205-237.
4. Lowe, W. C. (1968) Clin. Chem. 14, 1074-1079.

5. Logan, J. E. (1972) CRC Critical Review in Clinical Laboratory Sciences. 3, 271-289.

6. Gerironi, G. G., Ansley, J. D., Isaacs, J. W., Kutner, M. H. \& Rudman, D. (1976) Clin. Chem. 22,663L666.

7. Oberholzer, V. G., Schwarz, K. B., Smith, C. H., Dietzler, D. N. \& Hanna, T: L. (1976) Clin. Chem. 22, 1976-1981.

J. E. Buttery, Ph. D.

The Queen Elizabeth Hospital Woodvilleẹ

South Australia 5011 